\title{
The Implementation Of U.S Foreign Policy Towards Gaza Strip
}

\author{
Rina Aulia Marcella ${ }^{1}$ \\ Faculty of Humanities, International Relation, \\ President University, Indonesia \\ e-mail: rina.marcella@president.ac.id
}

Aulia, R. (2022). The Implementation Of U.S Foreign Policy Towards Gaza Strip. Aptisi Transactions on Technopreneurship (ATT), 4(1), 26-35.

DOI: https://doi.org/10.34306/att.v4i1.220

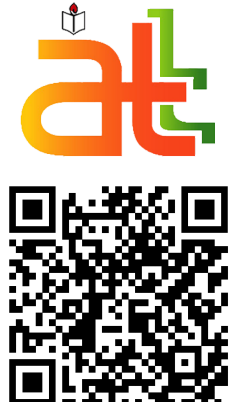

Author Notification

20 December 2021

Final Revised

01 January 2022

Published

19 January 2022

\begin{abstract}
This paper examines how the United States' foreign policy towards the Gaza conflict is being implemented. Furthermore, this paper discusses the United States' performance, attempts, technology use and outcomes in striking an agreement between Israel and Palestine. The goal of this analysis is to look at the United States' attempts in the long and near term to reintegrate the Palestinian authority into the democratic system and stabilize Gaza. According to the findings of this research, the United States has a strong commitment to community development and protection for a secure, free, democratic, and stable Palestinian government using technology in era 4.0. In order to achieve peace, the United States remains committed to a solution in which both Israel and Palestine, specifically Israel and Palestine, are equally entitled to the same level of freedom, security, and prosperity. The United States contributes to the delivery of bilateral assistance both in the economic and military fields.
\end{abstract}

Keywords: U.S Foreign Policy, Gaza, Israel - Palestinian, Foreign aid, Implementation.

\section{Introduction}

The American system is based on economic corporation interests, which fundamentally, involves a perpetual external cultivation and prioritizes a balanced environment with removing and minimizing any obstacles that can have an impact for growth limitation. American reactions in the middle east are triggered by the importance of U.S economic interests in that region. Arab-Israeli conflict has threatened middle east stability and has compromised the U.S crucial interest to stabilize them.

American support as a national and democratic country for Israel is a historic duty which has played an important role in the survival of the region's first democratic states. U.S and Israel have a long-term relationship which are based on the same common principles, share the same economic interests and promote common security using great system technology. The United States also values its commitment for human rights around the world, especially Palestinians prestige, warranty, and right to self- determination.

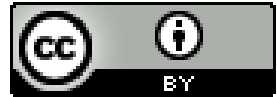

Copyright $@ 2022$ Rina Aulia Marcella ${ }^{1}$

This work is licensed under a Creative Commons Attribution 4.0 (CC BY 4.0) 
Congress has been a key holder in setting United States policy towards Palestine since the creation of the Palestine Liberation Organization (PLO) in the 1990s.1 The process of resolving the conflict between Israel and Palestine was influenced by the Congress which encouraged the government executive to negotiate a resolution to the conflict. Furthermore, they also help to fight against Palestinian terrorist groups, also allocate aid to Palestine. Since the signing of the Declaration of Principles between Israel and the PLO in 1993, the United States Congress has allocated more than $\$ 5$ billion in bilateral aid to Palestine.

The establishment of Palestinian sovereignity and the revocation of Israeli troops from West Bank and Gaza were started by OSLO Accords in 1993. Signed by Yitzakh Rabin, Israeli Prime Minister, and Yasser Arafat, the chairman of PLO.2 The growth of the Israeli population living on the west bank, Israel's prolonged military presence on the west bank, and a siege in Gaza are all hampered the peace process. Since the OSLO I agreement between Israel and Palestine in 1993, the U.S has provided bilateral assistance to Palestine. Furthermore, the OSLO II Accords which were signed in1995, have expanded the previous agreements by forcing Israel's full withdrawal from six West Bank cities and 450 cities.

International diplomacy aimed at resolving Israeli-Palestinian conflicts and furthering Palestinian national ambitions has stalled, with no direct talks between Israel and the Palestinian Liberation Organization (PLO) taking place since 2014. Palestinians frequently claim that US policy is biased in favor of Israel and ignores PLO Chairman and PA President Mahmoud Abbas' domestic political conflict with Hamas. Over the years, the US has prioritized fostering or finding a sustainable Israeli-Palestinian peace process, assisting the West Bank-based Palestinian Authority in combating Hamas and other terrorist groups, and utilizing aid to encourage Palestinian governance reform and economic development.

The conflict was also a watershed moment in US foreign policy as it prompted Arab oil producers to assert a severe oil embargo on the U.S and take the US, which supports Israel, and the Soviet Union, which arms Egypt and Syria, very close to nuclear war after the détente period. The Arab League recognized the Palestine Liberation Organization (PLO) as "the sole legal representative of the Palestinian people" in 1974, which was a windfall for the Palestinian cause.

The Gaza Strip poses difficult policy issues for the United States. Hamas, Israel, the Palestinian Authority, and a number of other outside parties all have an impact on Gaza's tough security, political, and humanitarian problems such as restrictions on the use of the internet and other technology advances in accessing information. These issues have fostered frequent conflict between Israel and Hamas (along with other Palestinian terrorists stationed in Gaza) since Hamas assumed de facto control of Gaza in 2007.

\section{Literature Review}

According to Holsti (1992: 271 - 285), foreign policy is influenced by two factors, namely internal and external. Internal factors are influenced by socio-economic conditions, geographical and topographical characteristics, national attributes, structures and philosophies of government, public opinion, and bureaucracy. While the external factors consist of the structure of the international system, the world economy, the goals and actions of other actors, regional and global problems as well as international law and world opinion. In this case, the conflict between Israel and Palestine makes the foreign policy of the United States to take part in its resolution due to the regional territorial problems that occur.

The Israeli-Palestinian conflict is the result of a century-old territorial clash over the Holy Land, a Middle Eastern region with religious and historical significance for Christians, Jews, and Muslims. Following the publication of Theodor Herzl's The Jewish State in 1896, which advocated for Jews to be able to seek refuge in their historic homeland to avoid anti-Semitism in Europe, an increasing number of Jews began to migrate to Ottoman Palestine, which was mostly Arab.

Zionism, as a Jews dream to return to their ancient homeland. The migration of European Jews to Palestine is spawned. In contrast, Arab nationalism which infused by indigenous inhabitants of Palestine has a burning desire to achieve the independence from foreign political rule. Zionism, although its rooted for reached the antiquity, its only emerged as 
a term of political force in Europe. The political activists, Theodor Herzl, gave birth to a political Zionism that aimed to reestablished a Jewish presence in Palestine. They organized a Yishuv, a Jewish community. According to various scholars, the Yishuv originally adhered to the ideals of social justice, human fraternity, and eschewed political power and military power. However, due to there's an early environment confrontation in Palestine, the birth of an emphatic ideology that rationalized the political power, coerce and domination over Palestinian Arab was born, namely militant ideology. On the other hand, Arab nationalism promotes an Islamic reform, territorial patriotism, and pan - Arab identification. According to Rashid Khalid, Palestinian nationalism rising in the early twentieth century as a result of an enclosure to Jerusalem, local politics, cultural activities, the Arab revolution in 1936-39, and contrariness to Zionism. By the 1930s, some of the U.S citizens had started to emphasize President Roosevelt to bolster Zionism. At the same time when Roosevelt attempted to stabilize diplomatic interest and domestic politics, his policy to Palestine became indistinct and inconstant. Forward to the 1940s, the U.S officially counted a few political interests in the Middle East. In spite of such domestic tension, Roosevelt put national security first during the war.

In 1943, in order to maintain a good relation with Saudi Arabia, due to they were partners during World War 2, President Roosevelt declared to provide military and economic assistance and stationed U.S. troops there. U.S officials also recognize the commercial importance of the Arab states. In 1947, 2.813 U.S ships arrived at Suez Canal, and U.S investors owned 23,75 percent of Iraq's oil industry. Nevertheless, U.S valued the cultural, as well as the political factors in Middle East. United states also expand a comprehensive savor in Saudi Arabia. Throughout and since World War II, by providing a generous foreign aid at Dhah-ran.

In early 1948, the U.S government face a dilemma on whether they are going to support Arab due to an intense opposition, or had to recognize the state of Israel. United States found it hard to formulate a consistent policy towards the Palestine conflict. U.S officials faced with a stark choice due to the declaration of Israeli statehood is confronting them.

Moving forward to Obama Presidency in 2010, the administration which lead by President Obama tried to renewed the effort to resolved the conflicts with new negotiations. $\mathrm{He}$ is preparing a "Letters of Negotiations" that are going to insure the Palestinians that the basis of the negotiations are going to be formed by the 1967 borders, and some demographic changes in post -1967 will be calculated for the Israelis. Clinton, secretary of the United States stated that the administration was on duty to take steps and re-release the palaver without any preconditions. Clinton also said that a settlement would reconcile "an independent and viable state based on the 1967 lines to actualize the Palestinians goals, on the other hand it will also create a secure and acknowledged borders for the Israelis.

On January 6, the expectation for progress on political negotiations, security, and Palestinian economic growth and institution building is expressed by Mitchell. According to him, Israel security and the formation of the state for Palestinians are "mutually reinforcing", which means "Palestinians are not going to get a state until the Israelis have a rational sense of sustainable security, and vice versa."6

On January 8 , the ideas of peace negotiations for the Palestinians is formularized by Saeb Erekat (The head of PLO Negotiations Department) and Egypt's intelligence chief, Umar Sulaiman. Firstly, based on the 1967 borders, the goal should establish Jerusalem as Palestine's capital. Second, Israel should stop the activity, including the natural accretion in Jerusalem totally, for six months. Lastly, the negotiations should from the point reached on December 8.7. At January 13, Hillary Rodham Clinton, secretary of state-designate gave a confirmation. Clinton said that the United States would never negotiate Hamas until they recognize Israel. Hillary also stated that the Gaza conflict during December 2008 - January 2009 will seek a lasting peace agreement that brings real security to Israel for the positive with its neighbors, and independence, economic progress, and security for Palestinians in their own country. 8 President Obama held a meeting with Israeli Prime Minister Ehud Olmert, 
Jordanian King Abdullah II, Palestinian Authority President Mahmud Abbas, and Egyptian President Hosni Mubarak on January 21 to express his duty to actively participate to the engagement in the event of Arab-Israeli peace from the start of his presidency. Since World War II, Israel has received the most foreign aid from the United States. Given the strong of U.S domestic support for Israel and its security, shared Middle East strategic goals, a shared commitment to democratic dignity, and historical ties dating back to US support for Israel's creation in 1948. Successive U.S administrations have provided significant assistance to Israel, working with Congress. 10 Thus far, U.S has suplied Israel with $\$ 146$ billion in bilateral assistance and missile defense money (in current, non - inflation - adjusted dollars). In 1947, the United Nations General Assembly voted to establish two Palestinian governments, one Jewish and the other Arab, following years of Arab-Jewish conflict.

In the Gaza Strip, there are around two million Palestinians and three million in the West Bank. Although the majority of Israel's 9.2 million residents are Jewish, the country also has a population of roughly two million Arabs.11 Attempts by international diplomats to broker a political completion have yielded little progress. Similarly, the US has attempted to resolve the Israeli- Palestinian issue, which has been a major driver of regional dynamics, in order to achieve these strategic goals while balancing its support for Israel and striving for broader regional stability. At the same time, the crisis has caused significant concern among American Jews and Christian Evangelicals, both of whom are fervent supporters of Israel. However, some experts feel that the US's interest in ending the war has waned in recent years.

\section{Data Measurement}

The main focus in the content analysis consisting of several core issues that U.S foreign policy has focused on resolving the conflicts, that are:

- Borders. The two-state solution has been the main purpose for the International Support to resolve the Israel-Palestine conflict. For decades, international support has been strong for the idea of two independent states, one Israeli and the other Palestinian. This is known as the two-state solution. The majority of international diplomacy seeking a two-state solution supports Israel's return to pre- 1967 borders, but there is no agreement on how to explain Palestinians who stayed within the borders and Israeli Jews who stayed outside them.

- Jerusalem. The clashed city is located on the Israeli-West Bank line. Jerusalem has been appointed by Israel as its capital, whereas East Jerusalem was appointed by the Palestinians as theirs. East Jerusalem which is claimed by Palestinians as its capital would be compulsory for a two-state solution.

- Refugees. One million Palestinian refugees were formed as a result of the conflicts in 1948 and 1967. The survivors and their descendants, most of whom live in Jordan, Lebanon, and Syria, say that they have the right to return to Israel, as stated in a UN General Assembly resolution passed in 1948. The question of whether survivors' descendants should be deemed refugees with that right is still being debated. Israel views the right of return as a hazard to its Jewish statehood, and argues that the evacuee should be relocated to a Palestinian state established as part of a two-state solution.

- Security. Some Palestinian terrorist groups, particularly Hamas, the Islamist organization that administers Gaza and has promised to destroy Israel, are seen as existential dangers by Israel. It usually targets Israeli civilians with suicide bombers and missile assaults. Israel wants these groups to disarm and the Palestinian state to be demilitarized, but it recognizes the need for a robust police presence in the Palestinian territories. The Palestinians want an end to Israel's military occupation and complete control over their own security, but they are willing to accept weaponry restrictions. Israel wants to keep its authority to operate in Palestinian territory in the event of a security danger.

- Mutual recognition. Each side wants the other, as well as the international community, to recognize its state. The majority of Israeli Jews want Israel to be 
acknowledged as a Jewish state, whereas Palestinians want Israel to recognize the Nakba, or forced displacement.

- End of conflict. Both parties want a peace accord that will end their war, honor each side's claims, and lead to peace and normalization of Israel's relations with all Arab governments, as the Arab Peace Initiative calls for.

Despite long-standing support for a two-state solution, the United States has traditionally refused to support Palestinian state ambitions at the UN, arguing that the issue should only be resolved through negotiations with Israel. Since 2011, the Palestinian Authority has asked for Palestine to become a full member of the United Nations, a decision that requires the approval of the Security Council, where the United States exercises its veto power. Data for this research was taken from the official website of Congressional Research Service that consist of the implementation of united states foreign policy by giving both sides (Israel - Palestine) foreign aid during the conflict. The measurement of this analysis is also considering the U.S position in each side, Jerusalem, Palestine, and also Israel.

- U.S position in Palestine Clinton outlined the skeleton for stipulating a Palestinian state and completing the remaining latest status thoughtfulness. The first U.S support for Palestinian state was coming from George W. Bush, which outlined in United Nations'2003 Road Map for Peace by United States, Russia, and European Union.

- U.S position in Jerusalem Israel and PLO (Palestinian Liberation Organization) agreed in the 1993 Oslo Accords, the last comprehensive accord on the subject, that the claim to Jerusalem would be fixed only in final status discussion. Today, Israel considers all part of Jerusalem to be its capital, whereas the Palestinian Authority claims East Jerusalem as their capitals for a future Palestinian state, and considers Israel's occupation of the region to be illegal. To avoid preempting a future peace accord, the US and most other countries having connections with Israel have retained their embassies in Tel Aviv for decades.

- U.S position on Israeli, For years, the U.S has officially opposed Israeli settlements as a barrier to peace, but has avoided naming them illegal outright in order to avoid international sanctions on Israel. Despite the fact that a 1978 State Department legal opinion said that Jewish settlements in occupied territory are unlawful under international law, President Ronald Reagan stated in a 1981 interview that the settlements were "ill-advised" but "not illegal."Most administrations came to bear in mind that in any peace deal, Israel would preserve its three largest accomplishment blocs in exchange for relinquishing other land to the Palestinians, believing that forcing so many of its inhabitants to leave the settlements was unfeasible. The United States, on the other hand, wields the most clout among the Gulf states, Israel, and the European Union (EU), and hence has a unique role to play in this means. As part of this venture, the United States should pressure the Gulf states and the Arab League to openly strain Hamas to accede the PA's competency, as well as boost Qatar's constructive role in supplying aid to Gaza, but ensure that Qatar's message to Hamas is that the Egyptian-United Nations-US plan is only political preference.

\section{Findings and Discussion}

\subsection{U.S foreign Aid to Palestinians}

United states administration which led by President Donald Trump, suggests that should persuade the Palestine Liberation Organization (PLO) to participate in U.S -led diplomacy on the Israeli-Palestinian peace process. U.S government had continuously espoused the Palestinians in charged of humanitarian contributions and economic protraction for the refugees in the Near East to UNRWA (United Nations Relief and Works Agency). Since 1944, the total of bilateral assistance that U.S gave to the Palestinian to promote the Israeli- Palestinian conflict peace process, improving the life of West Bank and Gaza 
populations has totaled more than $\$ 5$ billion. The foreign aid that United States provides for Palestinians is mostly in the form of supporting the governments, and humanitarian programs.

The 2018 changes raise the U.S political Influence, as well as the impact on other international actors, especially the Palestinian.14 These changed included:

- Reprogramming \$231.532 million in bilateral economic aid for West Bank and Gaza (containing $\$ 52$ million for East Jerusalem hospitals) for other purposes in FY2017.

- $\quad$ The United States' humanitarian assistance to UNRWA is being phased out. In FY2018, US funding was $\$ 65$ million, compared to $\$ 359,3$ million in FY2017.

- Choosing to exclude Palestinians from a conflict management and mitigation program (CMM) run by USAID and the US embassy in Jerusalem. Annually, $\$ 10$ million is allocated to programs engaging Israelis and Palestinians.

- The United States continues to provide nonlethal security aid to the Palestinian security forces, as well as security coordination with Israel, but the majority of Palestinians favor recent PLO proposals to stop the coordination

- The United States aid to Palestinians has changed more significantly in calendar year 2018 than at any point since 2007, when it was remodeled in response to the Sunni Islamist party Hamas' control of the Gaza Strip. According to some reports, the Anti-Terrorism Clarification Act of 2018 (ACTA, PL 115253), enacted in October 2018, could lead to the termination of US bilateral aid to the Palestinians if not any other congressional action (see "Terrorism Clarification Act 2018: Ending Bilateral Aid Possible").

Figure 1. Detailed U.S Bilateral Assistance to the Palestinians, FY2012 - FY2019

All FY2017 bilateral economic aid originally planned for the West Bank and Gaza appears to have been repurposed by the Trump administration. In September 2018, USAID reallocated an estimated $\$ 231.542$ million in ESF (including some labeled as ESF-OCO) from the West Bank and Gaza for other uses, based on congressional notifications. 
According to media sources, the Administration set aside $\$ 10$ million of the $\$ 26$ million allotted for CMM in FY2017 for efforts involving Israeli Jews-either with Palestinians from the West Bank or with Arab citizens of Israel.

\subsection{U.S Foreign aid in Israel}

After Israel withdrew from Arab countries as part of the peace process, the United States began to provide military aid. Israel was at risk for peace, and Washington considered it an obligation to provide this security aid. In return for their involvement in the peace process, the United States also provided a wide range of aid packages to Egypt and Jordan.

To date, the U.S has provided Israel with $\$ 146$ billion in bilateral assistance and missile defense money (in current, non-inflation-adjusted dollars).16 From 1971 to 2007, the United States provided Israel with important financial assistance. However, due to Israel's rapid economic growth since the 1990s, this is mainly done in the form of military aid. According to a 2016 memorandum of understanding, the U.S will provide Israel with approximately $\$ 4$ billion each year, including $\$ 500$ million for missile defense, indeed, the United States also giving such bilateral aid, migration and Refugees assistance to Israel.

- Migration and Refugees Assistance

Israel has received funding from the State Department's Migration and Refugee Assistance account (MRA)135 since 1973 to help with migrant relocation.17 The United Israel Appeal, a private philanthropic organization based in the United States, receives the contributions and distributes them to the Jewish Agency for Israel.18 136 Between 1973 and 1991, the US contributed $\$ 460$ million to Israel's resettling of Jewish refugees. Annual sums have ranged between $\$ 5$ million to $\$ 80$ million, owing in part to the large number of Jews fleeing the former Soviet Union and other places for Israel.

Table 1. Migration And Refugees Assistance Levels

\begin{tabular}{|c|c|}
\hline FISCAL YEAR & TOTAL \\
\hline FY2000 - FY2012 & $\$ 519.3$ million \\
\hline FY2013 & $\$ 15$ million \\
\hline FY2014 & $\$ 15$ million \\
\hline FY2015 & $\$ 10$ million \\
\hline FY2016 & $\$ 10$ million \\
\hline FY2017 & $\$ 7.5$ million \\
\hline FY2018 & $\$ 7.5$ million \\
\hline FY2019 & $\$ 5$ million \\
\hline FY2020 & $\$ 5$ million \\
\hline FY2021, Request & $\$ 5$ million \\
\hline
\end{tabular}

Technically, the legislation authorizes funding for refugee resettlement, but in Israel, there is little distinction made between Jewish "refugees" and other Jewish immigrants, and the monies are used to help all immigrants integrate.

\section{- Bilateral aid}

Proponents of foreign aid not only emphasize Israel's defensive and quality needs, but US aid to the United States and Israel is a mutual benefit, and the continued value of US aid to Israel is shown. They point out that American investments in 
Israeli defense and non-defense technologies have resulted in advancements in areas like missile defense, energy efficiency, and water supply.

Proponents of foreign aid not only emphasize Israel's defensive and quality needs, but US aid to the United States and Israel is a mutual benefit, and the continued value of US aid to Israel is shown. They point out that American investments in Israeli defense and non-defense technologies have resulted in advancements in areas like missile defense, energy efficiency, and water supply.

Table 2. U.S Bilateral Aid to Israel

\begin{tabular}{|l|r|r|r|}
\hline Fiscal Year & Economic & Military & \multicolumn{1}{c|}{ Total } \\
\hline $1951-2000$ & $29,266.4$ & $46,418.1$ & $75,684.5$ \\
\hline 2000 & $1,022.1$ & $2,841.3$ & $3,863.4$ \\
\hline 2001 & 850.4 & $1,989.0$ & $2,839.4$ \\
\hline 2002 & 726.7 & $2,061.2$ & $2,787.8$ \\
\hline 2003 & 657.0 & $3,088.6$ & $3,745.6$ \\
\hline 2004 & 556.8 & $2,165.5$ & $2,722.3$ \\
\hline 2005 & 482.1 & $2,231.4$ & $2,713.5$ \\
\hline 2006 & 285.8 & $2,257.8$ & $2,543.6$ \\
\hline 2007 & 168.0 & $2,341.7$ & $2,509.8$ \\
\hline 2008 & 44.3 & $2,381.2$ & $2,425.5$ \\
\hline 2009 & 40.3 & $2,383.0$ & $2,423.3$ \\
\hline 2010 & 36.3 & $2,801.3$ & $2,837.6$ \\
\hline 2011 & 37.1 & $3,009.5$ & $3,046.5$ \\
\hline 2012 & 25.1 & $3,175.6$ & $3,200.7$ \\
\hline 2013 & 17.5 & $2,985.8$ & $3,003.3$ \\
\hline 2014 & 23.4 & $3,103.2$ & $3,126.6$ \\
\hline 2015 & 12.3 & $3,281.0$ & $3,293.3$ \\
\hline 2016 & 13.3 & $3,100.0$ & $3,113.3$ \\
\hline 2017 & 50.2 & $3,175.0$ & $3,225.2$ \\
\hline 2018 & 10.8 & $3,117.6$ & $3,128.4$ \\
\hline Total & $\mathbf{3 4 , 3 2 6 . 0}$ & $\mathbf{9 7 , 9 0 7 . 7}$ & $\mathbf{1 3 2 , 2 3 3 . 7}$ \\
\hline
\end{tabular}

- A new U.S policy approach towards Gaza Strip

From the data above, we can see that the United States' humanitarian assistance to UNRWA is being phased out. To continue promoting such resolution in Gaza, it is clear to deduce that United states had to abandon some of the major policy decisions recently, like continue funding the UNRWA, specially in Gaza.21 Without 
such commitment, many key actors - most notably the Palestinian Authority - would be suspicious of American efforts, fearing that the US focus on Gaza is simply an attempt to permanently divide the Palestinian polity and eliminate the chance of a two-state solution. If the U.S is serious about improving the situation in Gaza, it should go beyond these measures. Such approaches like lightening the humanitarian, security, and economic crisis in Gaza could be done by U.S policy. Increase the amount of aid and the types of activities that the US is permitted to conduct in Gaza, allowing the labor in Gaza to return to Israel that can increase the number gradually while keeping security in mind, and should work to directly handle the water and electricity issues at the same time.

\section{Conclusion}

The United States policy towards Israeli-Palestinian issue has centered on ultimate ending talks between the Palestine Liberation Organization (PLO) and Israel. Because of those lack of focus, the United States policy toward Gaza has been reactive and unimaginative. When Hamas originally came to power in Gaza, the US pursued a policy of isolating and subsequently removing the group from the territory. After that failed, the US adopted a more stagnant strategy, compared to others. Policymakers considered the Gaza Strip as an afterthought that would be resolved once peace was established. With no imminent prospect of a peace accord, a proactive US policy on Gaza, as part of a broader frequency range to the Israeli-Palestine conflict, is no longer an option.

The situation in Gaza presents unusual hurdles, and the authors acknowledge that their recommendations may be rejected multiple times before they succeed. The framework outlined in this paper, on the other hand, offers the best prospect of escaping the current position. The authors aim to overcome the failed policies of the last 12 years by proposing an approach that focuses on both the political reunification of the Palestinian community and the long-term stabilization of Gaza. The United States can make a significant contribution to this. We need to play a more active role in Gaza and work closely with other foreign stakeholders, Israeli and Palestinians to end the ongoing disaster.

\section{References}

[1] Rynhold, Jonathan. The Arab-Israeli Conflict in American Political Culture. Cambridge Univ. Press, 2015.

[2] Hahn, Peter L. Caught in the Middle East U.S. Policy toward the Arab-Israeli Conflict, 1945-1961.University of North Carolina Press, 2004.

[3] Robinson, Kali. "What Is U.S. Policy on the Israeli-Palestinian Conflict?" Council on Foreign Relations. Council on Foreign Relations. Accessed October 30, 2021. https://www.cfr.org/backgrounder/what-us-policy-israeli-palestinian-conflict

[4] Heikal, J., Rialialie, V., Rivelino, D., \& Supriyono, I. A. (2022). Hybrid Model Of Structural Equation Modeling Pls And Rfm (Recency, Frequency And Monetary) Model To Improve Bank Average Balance. Aptisi Transactions on Technopreneurship (ATT), 4(1), 1-8.

[5] U.S. Department of State. (2021, June 16). U.S. relations with Palestinian Territories United States Department of State. U.S. Department of State. Retrieved October 30, 2021, from https://www.state.gov/u-s-relations-with-palestinian-territories. 
[6] Amr, H., Goldenberg, I., Huggard, K., \& Sachs, N. (2018, December 21). Ending Gaza's perpetual crisis: A new U.S. approach. Brookings. Retrieved October 30, 2021, from https://www.brookings.edu/research/ending-gazas-perpetual-crisis-a-new-u-s-approach.

[7] Council on Foreign Relations. (n.d.). Israeli-palestinian conflict | global conflict tracker. Council on Foreign Relations. Retrieved October 30, 2021, from https://www.cfr.org/global- conflict-tracker/conflict/israeli-palestinian-conflict.

[8] Surkes, S., staff, A. P. and T. O. I., Jeffay, N... AP, T. O. I. staff and. (2020, September 16). Israel's population up to 9.25 million, though growth rate, immigration down. The Times of Israel. Retrieved October 30, 2021, from https://www.timesofisrael.com/israelspopulation-up-to-9-25-million-but-growth-rate-immigration-down/\#gs.gfdll4 .

[9] United Nations. (n.d.). PLO sole legitimate representative of the Palestinian people - las rabat summit - resolution - question of Palestine. United Nations. Retrieved October 30, 2021, from https://www.un.org/unispal/document/auto-insert-194621/.

[10] Sharp, J. M. (n.d.). U.S. foreign aid to Israel - Congress. Retrieved October 30, 2021, from https://crsreports.congress.gov/product/pdf/RL/RL33222.

[11] Zanotti, J. (n.d.). U.S. foreign aid to the Palestinians - Congress. Retrieved October 30, 2021, from https://crsreports.congress.gov/product/pdf/RS/RS22967.

[12] Amsyar, I., Christopher, E., Dithi, A., Khan, A. N., \& Maulana, S. (2020). The Challenge of Cryptocurrency in the Era of the Digital Revolution: A Review of Systematic Literature. Aptisi Transactions on Technopreneurship (ATT), 2(2), 153-159.

[13] The Jewish Agency for Israel - U.S. (n.d.). Retrieved October 30, 2021, from https://www.jewishagency.org/.

[14] Council on Foreign Relations. (n.d.). What's at stake with the U.S. recognition of Jerusalem. Council on Foreign Relations. Retrieved October 30, 2021, from https://www.cfr.org/backgrounder/whats-stake-us-recognition-jerusalem.

[15] LUBIS, A., DALIMUNTHE, R., ABSAH, Y., \& FAWZEEA, B. K. (2021). The Effect of Corporate Communication and Service Quality on Customer Loyalty and Satisfaction in Sharia Banking. The Journal of Asian Finance, Economics, and Business, 8(3), 1267-127. 